La Chimica delle Fermentazioni

Microbiologia, Enzimologia, Chimica e Tecnica delle Fermentazioni. Da Virgilio Bolcato. Seconda edizione. Pp. xxiii + 665. (Bologna : Nicola Zanichelli, 1952.) 5,000 lire.

HIS book is divided into four parts : elements of general microbiology ; enzymology ; chemistry of fermentations; and technique of industrial fermentations. One of the virtues of the book is the excellent background and perspective to the pith of the dissertation (Part 3) provided by the other parts. In Part 3 itself, not only are modern views on the mechanisms of various fermentations presented, but also older schemes are critically discussed. A further desirable feature is the description of the methane fermentation, which is frequently neglected in text-books.

The main weakness of the book perhaps resides in undue brevity in certain sections, or in actual omissions. Thus, the reviewers feel that, in Part 1, more detailed treatment should be given to the role of micro-organisms in Nature, with particular reference to the carbon and nitrogen cycles. Again, the section on classification of micro-organisms would benefit by precise definition of the bacteria, yeasts and moulds in the organic world, and by some detail of the chief families and genera comprising the bacteria. The production of antibiotics is not treated. Reference is made to quite recent developments in enzyme chemistry, often, however, most briefly, although references are given. Indeed, there are a good, up-to-date bibliography, and subject and author indexes.

Whatever its shortcomings, the virtues of the book far outweigh them. It is unfortunate that this book does not exist in English translation, for it is admirably suitable as a text-book for students of microbiological chemistry and the associated field of plant biochemistry.

\section{R. H. Hopkins}

C. RaINBow

A School Course in Mechanics

By A.J. Bull. Part 2. Pp. viii + 157-408. (Cambridge : At the University Press, 1953.) 15s.

7 HIS volume, together with its more elementary companion, Part 1 , is designed to provide a continuous course reaching the standards required for the papers at Advanced and Scholarship levels for the various General Certificate of Education examinations, though the author states that students wishing to prepare for open university scholarships will need to supplement it by some other book. There is no doubt that, on the whole, the author has admirably succeeded in his aim. There is evidence of a well thought-out plan and a very satisfactory presentation which suggest that Mr. A. J. Bull has great enthusiasm both for his subject and the teaching of it.

In this volume, calculus is, quite properly, used freely, and there is a wide selection of questions, many of university standard; in addition, quite a number of typical questions are fully worked out in the text.

The need for practical work as an integral part of the course is stressed, though it must be said that the author does not approach many of the topics from the experimental aspect. This makes the book severely theoretical, and although those who are more mathematically minded will not be affected, the reviewer feels that an experimental approach to some of the problems dealt with would be helpful to the more ordinary student. There can be little doubt, however, that in his own teaching practice, Mr. Bull does introduce practical work in support of the text-book theory, and he exhorts other teachers to do likewise.

\section{ASTM-IP Petroleum Measurement Tables}

British edition : British (Imperial) Units of Measurement. Prepared jointly by the American Society for Testing Materials and the Institute of Petroleum. Pp. Xv +416. (London: Institute of Petroleum, 1952.) $50 s$.

NE of the latest joint efforts of the American Society for Testing Materials and the Institute of Petroleum is the publication of "ASTM-IP Petroleum Measurement Tables" (official designations being respectively $D 1250$ and IP 200), based on collective work started in 1946. The magnitude of the task can be readily imagined when it is realized that this and companion volumes contain thirty-nine tables involving some six hundred thousand six-digit figures (nearly four million digits); well over a quarter of a million IBM cards, weighing more than two tons, were employed in their make-up. These tables meet a demand from the oil industry and are authoritative in a computation of British (Imperial) units of weights and measures. They form part of a trilogy, including volumes devoted to United States and metric systems. The present (British) book includes tables for specific gravity and volume reduction to $60^{\circ} \mathrm{F}$., and for weights per unit volume and volumes per unit weight over the gravity range $0 \cdot 500-1 \cdot 000$, generally at intervals of $0 \cdot 001$. There are twenty-three separate tables in this volume, each of which is preceded with information as to purpose of the table, and also examples of how to use the data given. The completeness and accuracy of these tables are a major credit to all concerned in their compilation and, moreover, ensure a heavy international demand for this work, not only in the petroleum industry but also in a much wider field of applied science.

H. B. MILNER

Alternating Current Wave Forms

Theory and Practice. By Philip Kemp. (Monographs on Electrical Engineering, Vol. 1.) Second edition, revised and enlarged. $\mathrm{Pp} . \mathrm{xi}+406$. (London : Chapman and Hall, Ltd., 1952.) 50s. net.

NR. PHILIP KEMP'S book dealing with alter$V 1$ nating current wave forms is one of considerable general utility to electrical engineers. It deals with the synthesis and harmonic analysis of complex periodic waves, and with the properties of such waves in relation to electrical networks.

Only elementary mathematics is involved, and the book is very suitable for the use of undergraduate students. A good deal of attention is given to the harmonic-generating properties of circuits with ironcored reactors, and the production of harmonics by cyclic variation of resistance is also considered. Harmonics in polyphase systems and in transformers in various systems of connexion and when supplying rectifiers are treated in two chapters. Two further chapters are devoted to the study of harmonics in the flux waves in electrical machines, and to the generation of harmonic e.m.f.'s in alternatingcurrent windings.

The book gives a good general, but necessarily not detailed, treatment of the main features of the subject, both theoretical and practical. 